\title{
Ekstraksi Kembang sepatu (Hibiscus Rosa Sinensis L) Menggunakan Pelarut Metanol dengan Metode Sokletasi untuk Indikator Titrasi Asam Basa
}

\author{
Riniati $^{\mathrm{a}^{*}}$, Ahya Sularasa ${ }^{\mathrm{a}}$, Anri Dwi Febrianto ${ }^{\mathrm{a}}$

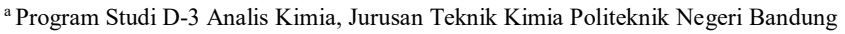 \\ * corresponding author: riniati@poban.ac.id \\ DOI : 10.20885/ijca.vol2.iss1.art5
}

\section{ARTIKEL INFO}

Received : Januari 2019

Revised : Februari 2019

Published : Maret 2019

Kata kunci : Kembang sepatu, indikator asam - basa, sokletasi, pelarut metanol

\begin{abstract}
ABSTRAK
Kembang sepatu merupakan tanaman hias yang tumbuh sepanjang masa dan banyak terdapat di daerah tropis. Ekstrak kembang sepatu diketahui dapat menunjukan hasil perubahan warna yang spesifik terhadap larutan asam maupun basa. Sifat ini dapat diterapkan sebagai indikator alami pengganti indikator sintetis yang harganya cukup mahal. Penelitian ini bertujuan untuk mengekstrak kembang sepatu kemudian memvalidasi penggunaan ekstrak tersebut sebagai indikator pada titrasi asam basa dengan pembanding indikator fenolftalein. Pelarut yang dipilih untuk ekstraksi antosianin dalam kembang sepatu pada penelitian ini yaitu metanol, dengan menggunakan metode sokletasi. Sokletasi dilakukan terhadap kelopak kembang sepatu yang sudah dikeringkan dan dipoton-potong pada kondisi suhu $68{ }^{\circ} \mathrm{C}$ dan dilakukan selama 15-20 siklus secara kontinyu. Ekstrak kemudian didistilasi dan di karakterisasi menggunakan FTIR selanjutnya diujicobakan sebagai indikator pada titrasi asam basa dengan pembanding indikator sintesis fenolftalein. Dari penelitian ini dapat disimpulkan bahwa ekstrak kelopak kembang sepatu menggunakan pelarut metanol dapat digunakan sebagai indikator titrasi asam basa dengan perubahan warna dari merah ke hijau muda pada range $\mathrm{pH}$ 5-9 dan kestabilan warna terjaga selama rentang waktu minimal 8 minggu. Dari hasil pengujian koefisien korelasi diperoleh nilai $\mathrm{R}=0,9992$ dan nilai \% recovery dari sebesar $101,16 \%$, dimana nilai tersebut memenuhi standar metode validasi analisis kimia, dengan demikian indikator ini layak untuk digunakan sebagai pengganti indikator fenolftalein.
\end{abstract}

\section{PENDAHULUAN}

Indikator asam basa adalah suatu zat yang dapat memberikan perubahan warna sesuai dengan $\mathrm{pH}$ larutan yang diidentifikasi serta dapat mengetahui sifat asam dan basa suatu larutan tersebut. Percobaan sains untuk menguji sifat suatu larutan asam basa merupakan modul penting yang biasa dilakukan di sekolah menengah umum maupun perguruan tinggi. Indikator sintetis yang biasa digunakan antara lain fenolftalein, kertas lakmus, brom timol biru dan metil merah Penggunaan indikator sintetik memiliki kertebatasan seperti harganya yang relatif mahal dan dapat menyebabkan pencemaran lingkungan. Oleh sebab itu, keberadaan indikator alami asam-basa dapat menjadi alternatif yang murah dan ramah lingkungan dalam penggunaan indikator asam-basa.

Salah satu bahan alami yang memiliki potensi sebagai indikator alami adalah tanaman kembang sepatu (Gambar 1). Diketahui, pengujian ekstrak kembang sepatu dapat menunjukkan hasil perubahan warna merah pada larutan asam dan perubahan warna menjadi hijau pada larutan basa. Hal tersebut dikarenakan kembang sepatu termasuk dalam satu familia Malvaceae yang memiliki senyawa antosianin sehingga dapat digunakan sebagai indikator alami. 


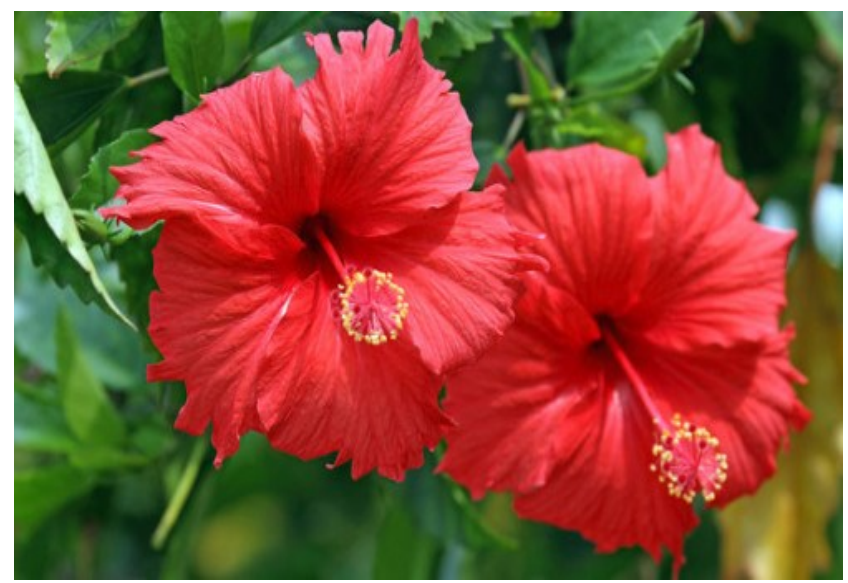

Gambar 1. Mahkota Kembang sepatu

Antosianin memiliki warna yang menarik dan tidak berbahaya bagi kesehatan sehingga banyak digunakan dalam industri pangan dan farmasi. $\mathrm{pH}$ dan struktur kimia dari antosianin berpengaruh terhadap karakter warna antosianin. [1]. Dalam keadaan netral (pH 7) akan tidak berwarna, pada asam $(\mathrm{pH}<3)$ akan berwarna merah sedangkan pada basa $(\mathrm{pH}>10)$ akan berwarna biru.) [2]. Studi fitokimia terhadap kembang sepatu mengungkapkan terdapat bahan-bahan kimia diantaranya flavonoid, flavonoid glikosida, hibiscetine, asam sitrat, asam tartrat, siklopropenoid dan pigmen antosianin [3]. Antosianin pada kembang sepatu adalah jenis pelargonidin [4]. Antosianin adalah glikosida dari antosianidin merupakan senyawa organik golongan fenolik. Sampai saat ini, setelah diidentifikasi lebih dari 540 pigmen antosianin dapat memberikan warna biru, merah, oranye atau ungu [5]. Pigmen yang dihasilkan dari tanaman sekitar 2000 pigmen, 150 diantaranya telah diekstrak dan dimanfaatkan sebagai obat [6] [7].

Metode yang dapat digunakan dalam ekstraksi antosianin diantaranya sokletasi. Prinsip dari sokletasi yaitu penyaringan yang berulang-ulang sehingga hasil yang didapat sempurna dan pelarut yang digunakan relatif sedikit. Pelarut yang digunakan dalam metode sokletasi yaitu yang mudah menguap dan dapat melarutkan senyawa antosianin yang terdapat dalam bunga kembang sepatu tetapi tidak melarutkan zat padat yang tidak diinginkan. Pelarut yang seringkali digunakan untuk mengekstrak antosianin adalah air (akuades), namun kelemahan penggunaan pelarut air berkaitan dengan tingkat kestabilan zat warna ini dalam dalam jangka waktu lama. Selain air, sering digunakan pelarut alkohol dan diketahui pelarut metanol memiliki konstanta dielektrik yang lebih besar dibandingkan pelarut etanol. Dari uji coba pendahuluan, diketahui pelarut metanol memberikan warna merah yang cukup stabil dibandingkan pelarut etanol sehingga metanol dipilih sebagai pelarut.

Tujuan dari penelitian ini yaitu untuk mengekstraksi zar warna antosianin dengan metode sokletasi menggunakan pelarut metanol. Ekstrak kembang sepatu dimanfaatkan sebagai bahan indikator alami untuk penentuan kadar asam basa dengan metode titrasi. Validasi pengujian linearitas dan \% recovery ekstrak kembang sepatu secara titrimetri menggunakan pembanding indikator sintetis fenolftalein.

\section{METODE}

\subsection{Alat}

Alat-alat yang digunakan dikelompokan menjadi tiga bagian yaitu:

a. alat-alat sokletasi dan distilasi seperti: tabung soklet, labu distilasi, kondensor spiral, penangas air, selang, penangas air.

b. Alat-alat titrasi seperti: buret, labu Erlenmeyer, labu seukuran, pipet seukuran, corong, botol timbang, batang pengaduk, botol semprot, pipet tetes, gelas kimia, klem buret dan statif.

c. Alat instrument spektrofotometer FTIR. 


\subsection{Bahan}

Bahan-bahan yang diperlukan dalam penelitian ini yaitu: kelopak kembang sepatu berwarna merah; pelarut metanol; larutan $\mathrm{HCl}$ dan $\mathrm{NaOH}$ dengan konsentrasi kurang lebih $0,1 \mathrm{~N}$; indikator fenolftalein, asam oksalat p.a, aquades, larutan buffer $\mathrm{pH}$ 1- 14.

\subsection{Prosedur Kerja}

\section{Preparasi dan Karakterisasi Kelopak Kembang sepatu}

Ditimbang sebanyak $50 \mathrm{~g}$ kelopak kembang sepatu segar, dikeringkan di udara terbuka selama 24 jam lalu dipotong kecil-kecil dengan ukuran kurang lebih $1 \mathrm{~cm}$. Selanjutnya dilakukan proses ekstraksi sokltelasi dengan menambahkan pelarut metanol sebanyak $500 \mathrm{~mL}$ dan di ekstrak sampai 15 siklus pada suhu $68{ }^{\circ} \mathrm{C}$. Setelah itu Filtrat hasil ekstraksi didistilasi sampai menghasilkan volume distilat menjadi setengahnya. Untuk karakterisasi keberadaan zat warna antosianin dikarakterisasi menggunakan FTIR. Secara kualitatif, pengujian rentang $\mathrm{pH}$ indikator dilakukan dengan meneteskan masing-masing 1 tetes indikator ekstrak kembang sepatu terhadap berbagai larutan $\mathrm{pH}$ buffer dari $\mathrm{pH} 1$ sampai 14 di atas plat tetes. Selanjutnya ekstrak kembang sepatu diuji sebagai indicator pada titrasi asam basa secara titrimetri.

\section{Pengujian Indikator Secara Volumetri: Titrasi basa kuat dengan asam kuat}

Memipet sebanyak $25 \mathrm{~mL}$ larutan $\mathrm{NaOH} 0,1 \mathrm{~N}$ yang sudah distandarisasi dalam erlenmeyer dan tambahkan beberapa tetes indikator ekstrak kembang sepatu hingga berwarna merah. Kemudian dititrasi secara triplo menggunakan larutan $\mathrm{HCl} 0,1 \mathrm{~N}$ sampai terjadi perubahan warna hijau (6 tetes atau $0,3 \mathrm{~mL}$. Titrasi asam kuat - basa kuat umumnya menggunakan indikator fenolftalein (rentang $\mathrm{pH}$ 8-9), sehingga indikator ini digunakan sebagai pembanding. Dilakukan percobaan yang sama dengan menggantikan indikator ekstrak kembang sepatu dengan indikator pembanding fenolftalein.

\section{Uji linieritas}

$10 \mathrm{~mL}$ titrat $\mathrm{HCl} 0,1 \mathrm{~N}$ dititrasi dengan titran $\mathrm{NaOH} 0,1 \mathrm{~N}$ menggunakan indikator ekstrak kembang sepatu. Pengujian dilakukan hingga 5 (lima) pengulangan.

\section{Uji \% recovery}

Uji \% recovery dilakukan dengan titrasi $\mathrm{HCl}$ dengan $\mathrm{NaOH} 0,1 \mathrm{~N}$ yang telah distandarisasi menggunakan indikator kembang sepatu. Titrasi dilakukan sebanyak enam kali pengukuran masing-masing pengukuran dilakukan duplo atau hingga memperoleh jumlah $\mathrm{NaOH}$ yang dibutuhkannya konstan.

\section{Uji kestabilan indikator alami}

Uji kestabilan dilakukan dengan titrasi $\mathrm{HCl} 0,1 \mathrm{~N}$ dengan $\mathrm{NaOH} 0,1 \mathrm{~N}$ yang telah distandarisasi, menggunakan indikator ekstraksi kembang sepatu. Mengingat keterbatasan waktu, pengujian ini dilakukan sebanyak 8 (delapan) minggu. 


\section{HASIL PENELITIAN}

\subsection{Ekstrak Kembang sepatu}

Proses ekstraksi sokletasi yaitu suatu proses transfer massa dari fase padat ke fasa cair yang lebih dikenal dengan ektraksi padat cair. Peristiwa ekstraksi sokletasi ini meliputi tiga tahapan yaitu difusi zat warna dari dalam padatan ke permukaan padatan lalu perpindahan massa zat warna dari permukaan padatan ke cairan dan difusi zat warna di dalam cairan sehingga ekstraksi sokletasi memungkinkan mengekstrak antosianin dari kembang sepatu tanpa merusak pigmen kembang sepatu tersebut dikarenakan tidak mengalami proses pemanasan langsung.

Ekstrak kembang sepatu didapat dengan mengekstraksi kembang sepatu dengan waktu 120 menit dengan suhu $68{ }^{\circ} \mathrm{C}$. Hasil ekstrak yang didapat kemudian dipekatkan dengan cara destilasi dan didapat masing masing destilat sebanyak $50 \mathrm{ml}$ dengan konsentrasi $\pm 24 \%$. Hasil ekstrak kelopak kembang sepatu dengan pelarut metanol, yaitu berwarna ungu, range $\mathrm{pH} 5-9$, dengan perubahan warna merah - hijau.

\subsection{Spektrum FTIR ekstrak kembang sepatu}

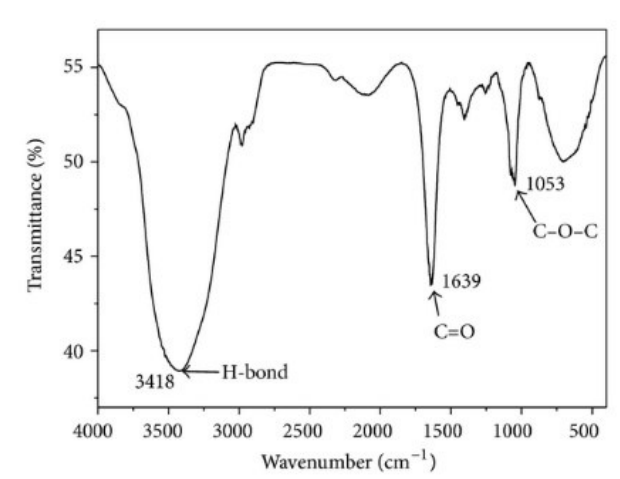

(a)

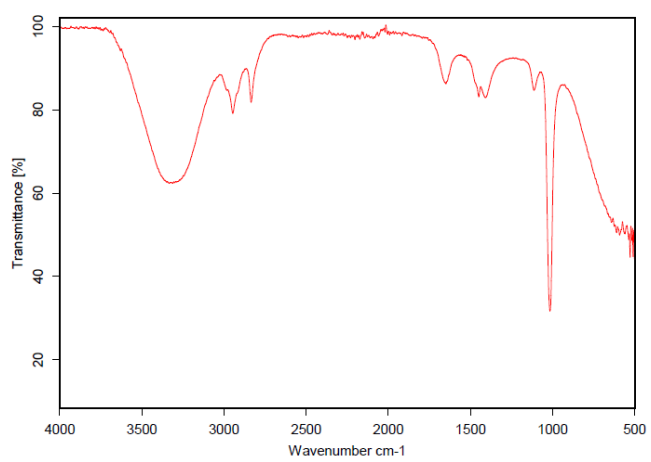

(b)

Gambar 2. Spektrum FTIR antosianin [8] (a) dan Spektrum FTIR ekstrak kembang sepatu (b)

Dari hasil spektrum Gambar 2, dapat dilihat ada kemiripan bilangan gelombang dari spektrum FTIR ekstrak kembang sepatu hasil ekstraksi menggunakan pelarut metanol dengan spektrum antosianin secara umum berdasarkan literatur. Dengan demikian ekstrak kembang sepatu dengan warna khas tersebut menunnjukkan karena adanya senyawa antosianin.

\subsection{Uji Linieritas akurasi / presisi dan uji Uji \% Recovery}

Pengujian linieritas akurasi dan presisi titrasi $\mathrm{NaOH}$ dengan $\mathrm{HCl}$ menggunakan indikator kembang sepatu dengan pembanding indikator fenolftalein dilakukan sebanyak 5 (lima) kali. Dari hasil pengujian yang ditunjukkan pada Gambar 3, diperoleh nilai koefisien korelasi menggunakan indikator fenolftalein yaitu sebesar $\mathrm{R}=0,9997$ sedangkan nilai koefisien korelasi menggunakan indikator ekstrak kembang sepatu $\mathrm{R}=0,9992$. Dari data yang diperoleh dapat disimpulkan menurut guidance for method validation in chemical analysis CIPAC 2010 bahwa pengukuran dapat diterima karena koefisien korelasi mendekati 1. 


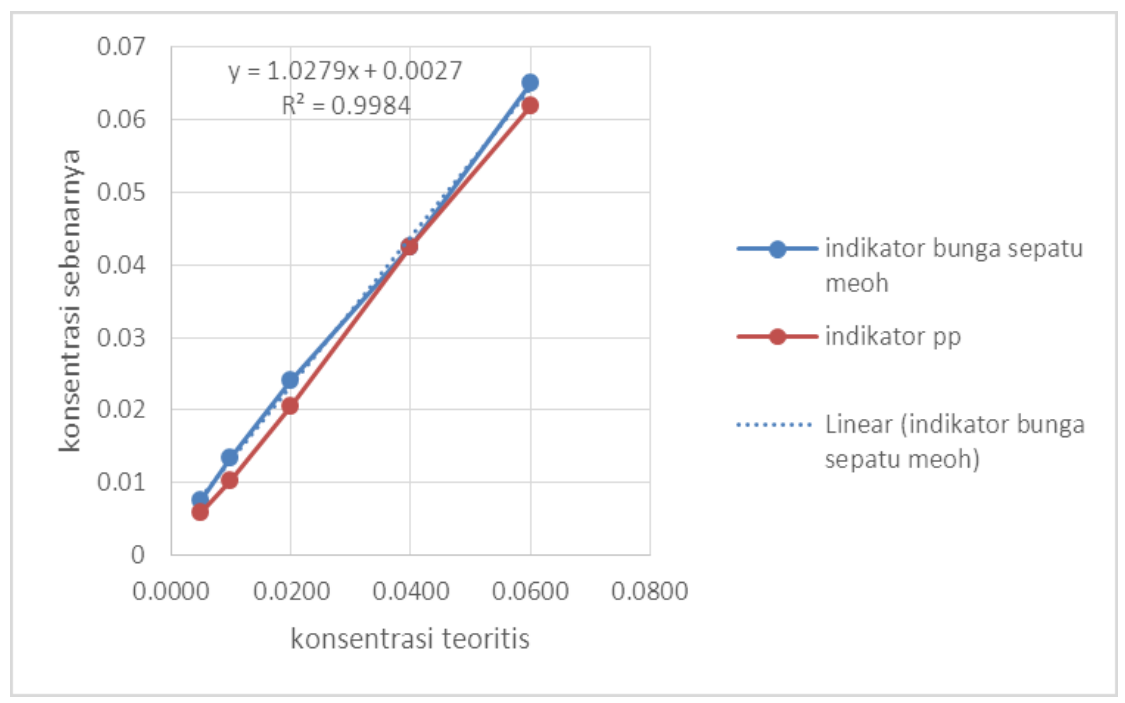

Gambar 3. Kurva linearitas titrasi $\mathrm{HCl}-\mathrm{NaOH}$ dengan indikator kembang sepatu dan pembanding indikator fenolftalein

Berikutnya dilakukan pengujian \% recovery yaitu dengan titrasi $\mathrm{HCl}$ dan $\mathrm{NaOH}$ yang telah diketahui konsentrasinya. Titrasi dilakukan sebanyak enam kali pengukuran masing-masing pengukuran dilakukan hingga memperoleh jumlah $\mathrm{NaOH}$ yang dibutuhkannya konstan. Dari pengujian yang dilakukan seperti tampak pada Tabel 1 . diperoleh nilai \% recovery dari indikator ekstrak kembang sepatu sebesar $101,16 \%$. Menurut guidance for method validation in chemical analysis CIPAC 2010 bahwa jika nilai \%w/w analit sekitar $0,1-1$ maka \% recovery yang diterima yaitu 85-115. Maka dapat disimpulkan pengujian \% recovery dapat diterima.

TABEL I. Uji \% recovery titrasi $\mathrm{HCl}-\mathrm{NaOH}$ dengan indikator kembang sepatu

Titrasi 10 mL HCl 0,0879 N dengan $\mathrm{NaOH}$ 0,1041 N menggunakan indikator Kembang Sepatu

\begin{tabular}{cccc}
\hline Titrasi & Volume $\mathrm{NaOH}(\mathrm{mL})$ & Konsentrasi $\mathrm{HCl}(\mathrm{N})$ & \% Recovery \\
\hline & & & \\
2 & 8,50 & 0,0885 & 100,67 \\
3 & 8,60 & 0,0895 & 101,85 \\
4 & 8,50 & 0,0885 & 100,67 \\
5 & 8,55 & 0,0890 & 101,26 \\
6 & 8,60 & 0,0895 & 101,85 \\
& 8,50 & 0,0885 & 100,67 \\
\hline
\end{tabular}

\subsection{Uji Kestabilan ekstrak kembang sepatu}

Uji kestabilan indikator ekstrak kembang sepatu dilakukan dengan pengulangan titrasi selama 8

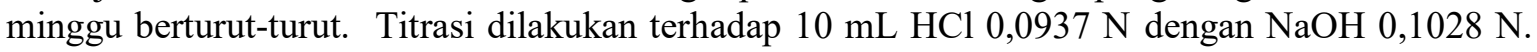
Volume titrasi yang dapat dilihat pada Tabel 2. 
TABEL II. Uji kestabilan indikator ekstrak kembang sepatu pada titrasi asam - basa

\begin{tabular}{ccc}
\hline Minggu ke & Volume $\mathrm{NaOH}(\mathrm{mL})$ & Perubahan Warna Titik Akhir Titrasi \\
\hline 1 & 8,70 & merah - hijau muda \\
2 & 8,60 & merah - hijau muda \\
3 & 8,65 & merah - hijau muda \\
4 & 8,70 & merah - hijau muda \\
5 & 8,60 & merah - hijau muda \\
6 & 8,70 & merah - hijau muda \\
7 & 8,60 & merah - hijau muda \\
8 & 8,70 & merah - hijau muda \\
\hline
\end{tabular}

Selama 8 (delapan) minggu pengulangan, secara visual tidak ada perubahan warna dari indikator ekstrak kembang sepatu dan volume titik akhhir titrasi relatif stabil. Dalam hal ini kestabilan tetap terjaga sama seperti pembanding indikator fenolftalein. Dengan demikian pelarut metanol sangat baik untuk ekstraksi antosianin pada kembang sepatu sebagai indikator asam-basa.

Penggunaan ekstrak kembang sepatu sebagai indikator asam - basa tidak hanya dapat diterapkan pada titrasi asam kuat - basa kuat (seperti $\mathrm{HCl}-\mathrm{NaOH}$ ) tetapi dapat juga diterapkan pada titrasi asam lemah - basa kuat, seperti titrasi asam asetat $\left(\mathrm{CH}_{3} \mathrm{COOH}\right)$ dengan $\mathrm{NaOH}$. Hal ini disebabkan karena $\mathrm{pH}$ titik ekivalen titrasi tersebut berada pada rentang $\mathrm{pH}$ perubahan warna indikator kembang sepatu yaitu $\mathrm{pH}$ 5-9.

\section{KESIMPULAN}

Dari penelitian ini, dapat disimpulakan, bahwa ekstrak kembang sepatu dengan pelarut metanol dapat digunakan sebagai indikator titrasi asam - basa dengan perubahan warna dari merah ke hijau pada rentang $\mathrm{pH}$ 5-9. Dari hasil pengujian diperoleh nilai koefisien korelasi $\mathrm{R}=0,9992$ dan nilai \% recovery sebesar $101,16 \%$, dimana nilai tersebut memenuhi standar metode validasi analisis kimia, dengan demikian indikator ekstrak kembang sepatu layak untuk digunakan sebagai pengganti indikator fenolftalein. Kestabilan ekstrak kembang sepatu tidak menunjukkan perbedaan perubahan warna maupun volume saat titrasi selama rentang waktu minimal 8 minggu pengulangan.

\section{Acknowledgment}

Penulis mengucapan terimakasih kepada Unit Penelitian dan Pengabdian Masyarakat (UPPM) POLBAN yang telah memberikan dana untuk penelitian ini melalui dana Penelitian Mandiri.

\section{Daftar Pustaka}

[1] A. D. Puspitasari dan L. S. Proyogo, "Perbandingan Metode Ekstraksi Maserasi Dan Sokletasi Terhadap Kadar Fenolik Total Ekstrak Etanol Daun Kersen (Muntingia Calabura), , J. Ilm. Cendekia Eksakta, pp. 1-8, 2013.

[2] S. T. Herwanto, dan S. H. Putri, "Aktivitas Antioksidan pada Minyak Biji Kelor (Moringa Oleifera L.) dengan Metode Sokletasi Menggunakan Pelarut N-Heksan, Metanol dan Etanol,” vol. 10, no. 2, 2016.

[3] S. Nuryanti, S. Matsjeh, C. Anwar, dan T. J. Raharjo, "Indikator Titrasi Asam-Basa dari Ekstrak Kembang Sepatu," Agritech., vol. 30, no. 3, pp. 178-183, 2010. 
[4] R.L Jackman, R.Y. Yada, M.A. Tung, and R.A. Speers, "Separation and chemical properties of anthocyanins used for their qualitative and quantitative analysis," A review. Journal of Food Biochemistry. vol. 11, pp. 179-208, 1987.

[5] Torskangerpoll, Qyvind, M. dan Andersen, "Colour stability of anthocyanins in aqulous solutions at various pH values," Journal of Food Chemistry, 89: 427-444, 2004.

[6] Anja, K., Latti, Kaisu, R., Riihinen, Pirjo, S. dan Kainulaine, "Isolasi and structure characterization of new anthocyanin derivat yellow pigments in oged red wines," Journal of Agricultural and Food Chemisrty 56: 190- 196, 2008.

[7] S. Nuryanti, dan D.P. Pursitasari, "Isolasi Antosianin pada Kembang sepatu (Hibicus rosa sinensis L) dan Penentuan Reliabilitasnya sebagai Indikator Asam-basa," Seminar Nasional UGM Yogyakarta, 2008.

[8 ] H. Chang, M. Kao, T. Chen, C. Chen, K. Cho, and X. Lai, "Characterization of Natural Dye Extracted from Wormwood and Purple Cabbage for Dye-Sensitized Solar Cells," Int. J. of Photoenergy, 2013 